\title{
Parental Involvement and the Academic Achievement of South Korean High School Students
}

\author{
Sera An \\ University of Pretoria, Pretoria \\ South Africa \\ Kammila Naidoo \\ University of Johannesburg, Johannesburg \\ South Africa
}

\begin{abstract}
Over the past few decades, South Korea, as a rapidly transforming society, has witnessed a massive drive for educational credentials. Some scholars suggest that South Korea has been gripped by an education fever that is leading to huge investments of economic and social capital to further young people's educational interests. This article refers to a study of three high-achieving South Korean schools. By conducting of a survey among 206 school students, 71 teachers, and 254 parents, this study aims to identify the key factors responsible for high educational achievement in the schools. Social capital and its relational, structural, and cognitive dimensions presented the conceptual and analytical tools of the study. The findings suggest, after all dimensions are considered, that familial social capital and the nature of parental involvement are most definitive for students' success. In this sense there is correspondence with James Coleman's (1988) views on the importance of family background as significant in determining how students ultimately perform. However, there is also an indication that mothers and fathers involve themselves differently - and that boarding school students benefit from retaining some distance away from family. The article concludes by offering a set of general recommendations useful for policy-makers in any society seeking to enhance students' educational achievements.
\end{abstract}

Keywords: social capital, parental involvement, educational achievement, South Korea 


\section{Introduction}

This article focuses on the social factors and relationships shaping the educational achievement of South Korean students. The need to understand what facilitates high achievement and consequently social mobility are central concerns in contemporary socioeducational studies in South Korea. A clearer understanding of what drives achievement is important in order to redress strategies to assist those who are currently under-performing. Schools have long been viewed as places in which opportunities can be equalized and as offering a foundation upon which all students, irrespective of their backgrounds, can attain higher social status and social position in society. To this end, access to the best schools and universities has become an urgent priority of families representing all classes in South Korea (Kim \& Lee, 2006; Shin, 2012).

Since the 1950s, after the Korean War ended, educational investment has played an extremely important role in the economic development of the country (Morris, 1996). The rapid economic growth of the newly industrialised countries in Asia (NICs) - South Korea, Singapore, and Taiwan - has depended, in particular, on industries which are based on human resources in the fields of science and technology (Clark, 2000: 122). Thus exemplary achievement in scientific and technical subjects is currently viewed in South Korea as a strong indicator of success at school, university, and in the marketplace. Universities have placed considerable effort on addressing the needs of the market, and schools have put in place policies and systems to ensure improved standards and continuous training often until the late hours of the night. Equalization policies have also been designed to benefit poorer children and boost the morale of under-achieving schools (Kim et al., 2004; Yu, 2006). There has, however, been much debate on whether the systems of the school or extra-school factors, such as family or community, have been most definitive in determining the success of school students (Choi, 2009).

The current study examines the educational achievement of South Korean $11^{\text {th }}$ graders by considering their performance alongside the social capital (SC) they have access to. Although social capital studies have tended to focus on academic prowess to examine educational inequality in many contemporary societies, few have seriously engaged with explaining the place of social capital in the expanding South Korean educational context. The intention of this article is to offer insight into the main factors (or aspects) of SC that are most influential in shaping student performance in what are viewed as generally 'high achieving' South Korean schools and then to consider whether this understanding offers general lessons for influencing changes in schools that are not performing optimally. 


\section{The Dimensions of Social Capital and its Link to Academic Achievement}

Social capital (SC) is commonly positively linked to both educational achievement (grades and test scores) and educational attainment (graduation and university enrollment) (An, 2005; Coleman \& Hoffer, 1987; Dika \& Singh, 2002; Sun, 1998). Parents play a role in the financial and moral support and guidance of their children in everyday circumstances and are thus somewhere at the center of SC formation (Lee, 2001; Wright et al., 2001). In developing countries, such as South Korea, the family is assumed to be quite influential in shaping educational outcomes (Chang, 2010) and the transference of wealth via familial inheritance practices sustains educational standing as well as class groupings; the latter evidenced by the tendency in South Korea to marry a partner with a similar level of education (Buchmann \& Hannum, 2001; Jang, 1999). As Bourdieu (1998) contends, this represents a marriage strategy essential for social reproduction. Parents from privileged class positions are likely to offer their children valuable support and also nurture high expectations in anticipation of their children's educational achievements. In popular discourse, the 'fever' for higher education in South Korean society is described as being driven by robust competition for positions in the upper echelons of society (Oh, 2000). While research has been conducted on the connections between social structures, institutions, and educational opportunities, there is still a need for more focused research within this field in South Korea: specifically, to explore the achievements of students in relation to family, school, and the community.

A perusal of scholarly works will illustrate that the issue of human relationships and social connectivity has concerned social theorists for a long time (Field, 2008; Halpern, 2005; Kim, 2005). Amongst the earlier twentieth-century scholars, social capital arguments were promoted by scholars such as Hanifan (1916) who, while his use of the term social capital is different from the way in which it is currently used, shifted the focus from the individual to cooperative structures and social networks. The concept of social capital is also linked to that of social exchange theory (Adler \& Kwon, 2002; Tsai, 2000) and is a relevant concept in the current field of educational sociology, where schools, school associations, and networks are viewed as engaging in competitive, cooperative, and socially transformative actions. Interest in the concept was heightened in the 1980s, proliferated in the 1990s, and became widely used in all branches of the social sciences by the 2000s. The core dimensions of social capital are drawn out from the classical theoretical works of Coleman (1988; 1994), Bourdieu (1998), and Putnam (2001), as illustrated in Figure 1 below. The theoretical approach framing the study was thus initially eclectic, with the intention being to allow the data analysis to guide us to the most relevant theorist for the South Korean context. 


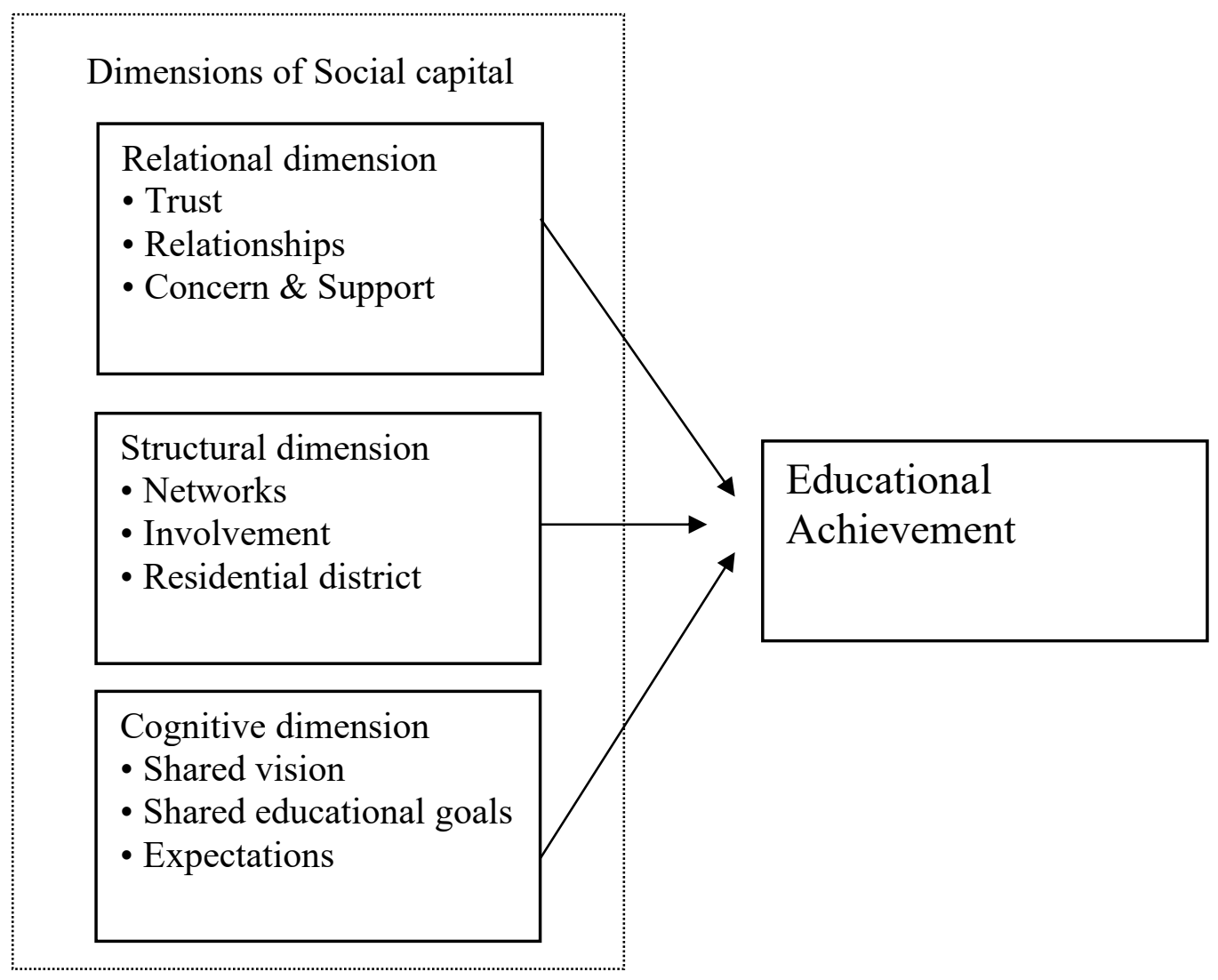

Figure 1: The core dimensions of social capital.

\section{Research Approach and Data Collection}

The design of the study is quantitative. However, in-depth qualitative interviews with three individuals were also later conducted to further explore some of the findings of the study. A survey was conducted in three relatively high-performing schools in South Korea; two of the three schools were in an urban area and the other was in a rural area. The three schools were selected purposefully, as examples of schools attaining on average strong overall academic results. Yangjae High School (YHS) is in the Gangnam $8^{\text {th }}$ zone in Seocho$\mathrm{Gu}$ in Seoul,and is a public, coeducational school. It has a high admission rate to SKY ${ }^{\mathrm{i}}$ with 49 students being admitted to SKY in 2009 (Choi, 2009). Jin (2006) found that levels of parental education were high in the Gangnam $8^{\text {th }}$ zone.

The second school in the sample is Daewon Foreign Language High School (DFLHS). It is the only one of its kind in South Korea. Daewon Foreign Language High School is an exceptionally high-achieving school located in Seoul. Three hundred and forty (340) of its students were admitted to SKY in 2009 (DFLHS, 2010). In addition, Daewon Foreign Language High School ranked $13^{\text {th }}$ in terms of high admissions to prestigious 
international universities, particularly those referred to collectively as the Ivy League (Bae, 2007); 37 students successfully entered the Ivy League in 2009 (Whang, 2009).

The third school is Sangsan High School (SHS) which is located in a rural area in Jeonju province. All students reside in dormitories as boarding is compulsory. Sangsan High School obtained high admission rates to prestigious universities in South Korea as well as to top British and American universities. Yangjae High School (YHS), Daewon Foreign Language High School (DFLHS), and Sangsan High School (SHS) differ in terms of school environments, and all three schools have large numbers of students representing different socio-economic groups. Table 1 illustrates total enrollment numbers in YHS, DFLHS, and SHS at the time of the fieldwork.

Table 1: Total Enrollment in YHS, DFLHS, and SHS; compiled from the websites of the schools, 2009

\begin{tabular}{lccc}
\hline & DFLHS & SHS & YHS \\
\hline \multirow{2}{*}{$10^{\text {th }}$ grade } & 432 & 383 & 485 \\
& $($ Boys 177/ Girls 255) & $($ Boys 255/ Girls 128) & (Boys 227/ Girls 258) \\
$11^{\text {th }}$ grade & 439 & 390 & 339 \\
& $(182 / 257)$ & $(256 / 134)$ & $(166 / 173)$ \\
$12^{\text {th }}$ grade & 441 & 374 & 339 \\
& $(192 / 249)$ & $(248 / 126)$ & $(156 / 183)$ \\
Total & $\mathbf{1 , 3 1 2}$ & $\mathbf{1 , 1 4 7}$ & $\mathbf{1 , 1 6 3}$ \\
& $\mathbf{( 5 5 1 / 7 6 1 )}$ & $\mathbf{( 7 5 9 / 3 8 8 )}$ & $\mathbf{( 5 4 9 / 6 1 4 )}$ \\
\hline
\end{tabular}

All the subjects were voluntary participants who took part freely after being informed of the purpose of the study. The sample size consisted of 531 persons from all three schools, with $20611^{\text {th }}$ grade students being a major part of this sample. Given that students work hard on their studies in an immensely competitive environment, they often do not have time for a face-to-face interview. Thus, self-administered questionnaires were used, because they could be filled in at a convenient time. A questionnaire was sent to the parents of the students who filled in the questionnaire. The researchers distributed the questionnaire personally to each teacher in all three schools, and collected them when done. Table 2 shows the final distribution of participants.

Table 2: Total distribution of questionnaires

\begin{tabular}{lcccc}
\hline & DFHS & SHS & YHS & Total \\
\hline $11^{\text {th }}$ graders & $70(35 / 35)$ & 78 & 58 & 206 \\
& $($ Boys/ Girls $)$ & $(39 / 39)$ & $(32 / 26)$ & \\
\hline
\end{tabular}


Parental Involvement and the Academic Achievement

\begin{tabular}{lcccc}
\hline Teachers & $\begin{array}{c}21(10 / 11) \\
\text { (Males/Females) }\end{array}$ & $\begin{array}{c}20 \\
(15 / 5)\end{array}$ & $\begin{array}{c}30 \\
(15 / 15)\end{array}$ & 71 \\
\hline Students' parents & $139(69 / 70)$ & 6 & 109 & 254 \\
& (Fathers/Mothers) & $(3 / 3)$ & $(51 / 58)$ & \\
\hline Total & $\mathbf{2 3 0}$ & $\mathbf{1 0 4}$ & $\mathbf{1 9 7}$ & $\mathbf{5 3 1}$ \\
\hline
\end{tabular}

The questionnaire was designed to take account of three types of social capital: familial social capital, school social capital, and community social capital. Each of the three types of social capital was linked to three dimensions: relational, structural, and cognitive. Firstly, in familial social capital, attention was paid to parental income, occupation, and family structure, etc. Secondly, school capital refers to school environment with regard to school type (boarding school or non-boarding school), contentment with the school curriculum and rules, etc. Lastly, in community social capital, satisfaction with issues such as security, facilities, and pride in community, etc. was assessed. These dimensions were viewed as dynamic, with the three types of SC being subject to shifts and changes over time (Nahapiet \& Ghoshal, 1998).

The relational social capital researched consists of conversations, trust, and relationships between students, parents, and teachers including their concerns and support. The structural social capital dimension refers to how the network among parents is structured, including the degree of involvement in terms of organisation, and regional characteristics in urban and rural areas. The last dimension is cognitive. It involves parental expectations of children, their awareness of children's weak subjects, closest friends, and construction of rules for children. If there is synergy between children and parents ,there are positive outcomes in the cognitive dimension. 


\section{Presentation of Results}

\section{Social and Demographic Characteristics of Students}

Table 3 offers detailed insights into students' characteristics.

Table 3: Social and Demographic Characteristics of Students

\begin{tabular}{|c|c|c|c|}
\hline \multicolumn{2}{|l|}{ Explanatory Variable } & $F(N=206)$ & $\begin{array}{c}\text { Valid } \\
\text { Percent }\end{array}$ \\
\hline \multirow{2}{*}{ Gender } & Male & 106 & 51.5 \\
\hline & Female & 100 & 48.5 \\
\hline \multirow{5}{*}{ Birth order } & The first child & 133 & 64.9 \\
\hline & The second child & 54 & 26.3 \\
\hline & The third child & 5 & 2.4 \\
\hline & The youngest child & 11 & 5.4 \\
\hline & Other & 2 & 1.0 \\
\hline \multirow{4}{*}{ Number of siblings } & One & 25 & 12.1 \\
\hline & Two & 150 & 72.8 \\
\hline & Three & 30 & 14.6 \\
\hline & four & 1 & 0.5 \\
\hline \multirow{5}{*}{$\begin{array}{l}\text { The housemate } \\
\text { (live with whom) }\end{array}$} & Both parents & 125 & 61.0 \\
\hline & Single parents & 10 & 4.9 \\
\hline & Friend (dormitory) & 61 & 29.8 \\
\hline & Alone & 4 & 2.0 \\
\hline & Other & 5 & 2.4 \\
\hline \multirow{6}{*}{ Religious affiliation } & Buddhism & 13 & 6.4 \\
\hline & Roman Catholic & 25 & 12.3 \\
\hline & Protestant & 53 & 26.0 \\
\hline & Muslim & 1 & 0.4 \\
\hline & No religious affiliation & 110 & 53.9 \\
\hline & Other & 2 & 1.0 \\
\hline \multirow{5}{*}{ Living condition } & Upper class (extremely wealthy) & 37 & 18.0 \\
\hline & Upper-middle class (wealthy) & 77 & 37.6 \\
\hline & Middle class (comfortable) & 72 & 35.1 \\
\hline & Lower-middle class (good standard) & 16 & 7.8 \\
\hline & Working class (meeting basic needs) & 4 & 1.5 \\
\hline \multirow{2}{*}{$\begin{array}{l}\text { Has close friend of } \\
\text { opposite sex }\end{array}$} & Yes & 22 & 10.7 \\
\hline & No & 184 & 89.3 \\
\hline \multirow{5}{*}{ Residential district } & Gangnam-gu & 26 & 12.6 \\
\hline & Seocho-gu & 64 & 31.1 \\
\hline & Songpa-gu & 12 & 5.8 \\
\hline & In Seoul & 25 & 12.1 \\
\hline & Except Seoul & 79 & 38.3 \\
\hline
\end{tabular}

A total of 206 students participated in a comprehensive mathematics test from the three schools, on 17 November, 2009, in South Korea. The students were thereafter categorized into three groups on the basis of their mathematics achievement score (MAS): the 
first group frequency was above 97 (high group/top achievers), the middle group/competent achievers was classified by a score range of 96 to 86, and the last group/low achievers was defined in terms of a score 85 and below. While it is recognized that categorizing learners on the basis of one subject and one test has limitations, it should be pointed out that great emphasis is placed on mathematics as a key indicator of performance in the South Korean educational system, and the test was guided by teachers with key insights on both curricula and teaching pedagogies. Thus, we find it useful to group students in this manner, in order to raise particular arguments later in this paper. The grouped frequency distribution table for the MAS is shown in Table 4.

Table 4: Grouped Frequencies for the MAS (Mathematics Achievement Score)

\begin{tabular}{|c|c|c|c|}
\hline Explanatory Vari & & $\mathrm{F}(\mathrm{N}=206)$ & $\begin{array}{c}\text { Valid } \\
\text { Percent }\end{array}$ \\
\hline \multirow{4}{*}{$\begin{array}{l}\text { The mathematics } \\
\text { achievement score } \\
\text { (MAS) }\end{array}$} & $\begin{array}{l}\text { The high group } \\
\text { (97 and above score) }\end{array}$ & 70 & 36.5 \\
\hline & $\begin{array}{l}\text { The middle group } \\
\text { (scores of } 96 \text { to } 86 \text { ) }\end{array}$ & 57 & 29.7 \\
\hline & $\begin{array}{l}\text { The low group } \\
\text { ( } 85 \text { and below score) }\end{array}$ & 65 & 33.9 \\
\hline & Missing system & 14 & \\
\hline
\end{tabular}

\section{Linking Scores to Demographic Characteristics of Students}

Considering the scores in Table 4, cross-tabulation was used to examine the differences among the three groups of students. The chi-square test $\left(\chi^{2}\right)$ was applied to establish the relationship between the categorical variables (Kremelberg, 2011). With this in mind, statistical significances were assessed and identified.

A number of the demographic characteristics of the students were not strongly related to the MAS: these include, for example, gender, number of siblings, home-mate (living with someone), religious affiliation, living conditions, and having an opposite-sex close friend (girl- or boyfriend). However, the following represented very important results: the birth order. The first child in terms of familial SC in the structural dimension shows a much higher score than the second child $\left(\chi^{2}=25.363, \mathrm{p}<.05\right)$. In this regard, parental expectations of their children can be a strong factor shaping children's educational performance (Coleman, 1994; Perna \& Titus, 2005; Schneider \& Lee, 1990). Perhaps parental expectations of the first-born 
child are higher than that of subsequent children, leading to positive encouragement which influences South Korean first-born children to attain much higher scores.

Regarding the home-mate (living with someone), boarding school students have a higher score than those who live with both their parents $\left(\chi^{2}=25.363, p<.01\right)$. It was found that the school SC in terms of the structural dimension has a greater effect on the students' educational achievement. With regard to the residential district, those students living in Gangnam-gu have a higher score than other residential districts $\left(\chi^{2}=50.750, p<.05\right)$. In Seo's (2004) research, parent's residential district was noted as quite crucial in determining children's education. Residential district is not only a residential brand but carries assumptions of prestige in terms of socio-economic and educational position. Many parents are attracted to the more elite area of Gangnam-gu specifically because they believe it will benefit their children's education (Jin, 2006). As a result of this situation, students in Gangnam-gu appear to live up to these expectations and are in a sense driven to achieve exemplary results. A summary of some of the results pertaining to student characteristics is shown in Table 5. 
Table 5: Comparison of the Scores and Student Characteristics $(\mathrm{N}=192)$

\begin{tabular}{|c|c|c|c|c|c|c|}
\hline \multicolumn{2}{|c|}{ Explanatory Variable } & $\begin{array}{c}\text { The } \\
\text { high N } \\
(\%)\end{array}$ & $\begin{array}{l}\text { The } \\
\text { middle } \\
\mathrm{N}(\%)\end{array}$ & $\begin{array}{c}\text { The low } \\
\mathrm{N}(\%)\end{array}$ & $\begin{array}{c}\text { Total N } \\
(\%)\end{array}$ & $\begin{array}{l}\chi^{2} \\
(p)\end{array}$ \\
\hline \multirow{2}{*}{ Gender } & Male & $38(54.3)$ & $36(63.2)$ & $27(41.5)$ & $101(52.6)$ & 5.818 \\
\hline & Female & $32(45.7)$ & $21(26.8)$ & $38(58.5)$ & $91(47.4)$ & $(.055)$ \\
\hline \multirow{5}{*}{ Birth order } & The first child & $56(80.0)$ & $37(66.1)$ & $31(47.7)$ & $124(64.9)$ & \\
\hline & The second child & $11(15.7)$ & $14(25.0)$ & $26(40.0)$ & $51(26.7)$ & 17.00 \\
\hline & The third child & $1(1.4)$ & $1(1.8)$ & $2(3.1)$ & $4(2.1)$ & $(.030)$ \\
\hline & The youngest & $2(2.9)$ & $4(7.1)$ & $5(7.7)$ & $11(5.8)$ & \\
\hline & Other & $0(0.0)$ & $0(0.0)$ & $1(1.5)$ & $1(0.5)$ & \\
\hline \multirow{4}{*}{$\begin{array}{l}\text { Number of } \\
\text { siblings }\end{array}$} & One & $9(12.9)$ & $4(7.0)$ & $11(6.9)$ & $24(12.5)$ & \\
\hline & Two & $48(68.6)$ & $47(82.5)$ & $45(69.2)$ & $140(72.9)$ & 6.133 \\
\hline & Three & $12(17.1)$ & $6(10.5)$ & $9(13.8)$ & $27(14.1)$ & $(.408)$ \\
\hline & Four & $1(1.4)$ & $0(0.0)$ & $0(0.0)$ & $1(0.5)$ & \\
\hline \multirow{5}{*}{$\begin{array}{l}\text { Home-mate } \\
\text { (live with } \\
\text { whom) }\end{array}$} & Both parents & $36(51.4)$ & $31(55.4)$ & $44(67.7)$ & $111(58.1)$ & \\
\hline & Single parents & $0(0.0)$ & $3(5.4)$ & $7(10.8)$ & $10(5.2)$ & \\
\hline & Friend & $31(44.3)$ & $20(35.7)$ & $10(15.4)$ & $61(31.9)$ & 25.36 \\
\hline & Alone & $2(2.9)$ & $2(3.6)$ & $0(0.0)$ & $4(6.2)$ & $(.001)$ \\
\hline & Other & $1(1.4)$ & $0(0.0)$ & $4(6.2)$ & $5(2.6)$ & \\
\hline \multirow{6}{*}{$\begin{array}{l}\text { Religious } \\
\text { affiliation }\end{array}$} & Buddhism & $6(8.8)$ & $6(10.5)$ & $1(1.5)$ & $13(6.8)$ & 11.27 \\
\hline & Roman Catholic & $9(13.2)$ & $7(12.3)$ & $9(13.8)$ & $25(13.2)$ & $(.336)$ \\
\hline & Protestant & $16(23.5)$ & $12(21.1)$ & $17(26.2)$ & $45(23.7)$ & \\
\hline & Muslim & $0(0.0)$ & $0(0.0)$ & $1(1.5)$ & $1(0.5)$ & \\
\hline & No affiliation & $37(54.4)$ & $30(52.6)$ & $37(56.9)$ & $104(54.7)$ & \\
\hline & Other & $0(0.0)$ & $2(3.5)$ & $0(0.0)$ & $2(1.1)$ & \\
\hline \multirow{5}{*}{$\begin{array}{l}\text { Living } \\
\text { condition }\end{array}$} & Upper class & $15(21.4)$ & $14(24.6)$ & $5(7.8)$ & $34(17.8)$ & 13.03 \\
\hline & Upper-middle & $26(37.1)$ & $19(33.3)$ & $25(39.1)$ & $70(36.6)$ & $(.111)$ \\
\hline & Middle class & $19(27.1)$ & $20(35.1)$ & $30(46.9)$ & $69(36.1)$ & \\
\hline & Lower-middle & $9(12.9)$ & $3(5.3)$ & $3(4.7)$ & $15(7.9)$ & \\
\hline & Working class & $1(1.4)$ & $1(1.8)$ & $1(1.6)$ & $3(1.6)$ & \\
\hline \multirow{2}{*}{$\begin{array}{l}\text { Opposite sex } \\
\text { friend }\end{array}$} & Yes & $7(10.0)$ & $5(8.8)$ & $9(13.8)$ & $21(10.9)$ & .902 \\
\hline & No & $63(90.0)$ & $52(91.2)$ & $56(86.2)$ & $171(89.1)$ & $(.637)$ \\
\hline \multirow{5}{*}{$\begin{array}{l}\text { Residential } \\
\text { district }\end{array}$} & Gangnam-gu & $10(14.3)$ & $7(12.3)$ & $7(10.8)$ & $24(12.5)$ & 50.75 \\
\hline & Seocho-gu & $3(4.3)$ & $16(28.1)$ & $38(58.5)$ & $57(29.7)$ & $(.000)$ \\
\hline & Songpa-gu & $7(10.0)$ & $2(3.5)$ & $1(1.5)$ & $10(5.2)$ & \\
\hline & In Seoul & $10(14.3)$ & $8(14.0)$ & $4(6.2)$ & $22(11.5)$ & \\
\hline & Except Seoul & $40(57.1)$ & $24(42.1)$ & $15(23.1)$ & $79(41.1)$ & \\
\hline
\end{tabular}

${ }^{*} p<.05, * * p<.01, * * * p<.001$

\section{Comparing Relationships of Student Respondents with Parents}

Twenty-three (23) questions were directed to both fathers and mothers with regard to relationships between parents and their children. The 23 questions were guided in terms of a Likert 5-point scale. ANOVA was applied to build comparisons between parents and the three groups of students (Muijs, 2011). It was apparent that when students have a strong 
relationship with their father, generally positive effects on their educational achievement ensues, according to the seven researched items. The relational dimension of familial SC is important in stimulating the child's educational achievement. When a father knows what his child's weak subjects are $(\mathrm{F}=4.193, \mathrm{P}<.05)$, when children speak to fathers about their concerns $(\mathrm{F}=4.590, \mathrm{p}<.05)$, or their more serious worries $(\mathrm{F}=5.108, \mathrm{P}<.05)$, positive effects are evident. If the father-child relationship is strong, students are more likely to achieve higher scores.

The structural dimension of a family's social capital also affects a child's educational achievement. Often fathers of higher-achieving students collect educational information, such as news and advertisements for their children $(\mathrm{F}=3.661, \mathrm{P}<.05)$. Significantly, when higherachieving students have to choose something, they tend to value advice from their fathers $(\mathrm{F}=5.049, \mathrm{P}<.01)$. High-achieving students are those who commonly discuss matters about school, friends, and teachers, with their father (often rather than their mother) more so than poor achieving students do $(\mathrm{F}=5.509, \mathrm{p}<.01)$. However, the low-achieving students were more frequently disciplined by their fathers, who would limit the watching of television and computer games $(\mathrm{F}=3.661, \mathrm{p}<.05)$ more often than the middle-achieving students.

The evidence shows that relationships with mothers have important effects on student's educational achievement. In fact, children's relationship with their mother has an overall greater influence on their educational achievement than the effects of their relationship with their father. There are some interesting associations noted here. When the mother knows what her child's weak subjects are $(\mathrm{F}=4.721, \mathrm{p}<.01)$, the student is likely to achieve higher scores. In this sense, knowing how the child is performing leads mothers to be proactive in getting information and taking interventionist measures $(\mathrm{F}=5.882, \mathrm{p}<.01)$. Linked to this, mothers guard or monitor friendship cliques of their children. Mothers are more strongly concerned about who their children's close friends are $(\mathrm{F}=3.812, \mathrm{p}<.05)$. By getting to know her child's close friends, the mother takes a strong interest in the life of the child at school — and potentially intercedes when she wishes to influence a change of friends in the interest of the child.

Such actions (as noted above) can ultimately affect the educational achievement of a student. In the case of higher-achieving students, it would seem that they speak mainly to their mothers when they have concerns $(F=4.334, p<0.5)$ and when they have more serious worries $(\mathrm{F}=4.044, \mathrm{p}<.05)$. Higher-achieving students discuss matters about friends and teachers with their mothers $(\mathrm{F}=4.014, \mathrm{p}<.05)$. The middle-achieving group has good relationships with their mothers, but this is not the case with the lowest-achieving group 
$(\mathrm{F}=5.784, \mathrm{p}<.01)$. As an outcome of their poorer performances, the group attaining the lowest scores refers to their mothers placing restrictions on their free time and disallowing time for watching television and playing computer $(\mathrm{F}=4.103, \mathrm{p}<.05)$, more so than the middleachieving group.

\section{Comparing Student Respondents Views on Schools}

Higher-achieving students express more pride in their school than lower-achieving students $\left(\chi^{2}=22.915, \mathrm{p}<.01\right)$, and students who attend schools in the same area in which they live are more likely to experience positive interactions with other students in the area, compared to others who move between wider distances (Israel et al., 2001). However, boarding school students have more time for self-study and are more concentrated in the higher MAS than students attending school in the same area where they live $\left(\chi^{2}=20.979\right.$, $\mathrm{p}<.01)$.

Altogether, six questions were asked about students' satisfaction with their school. Higher-achieving students seem to be quite satisfied with their school's internal school environment (e.g. classroom, equipment) $(\mathrm{F}=5.368, \mathrm{p}<.01)$ and the school policy for college admission $(\mathrm{F}=4.304, \mathrm{p}<.05)$. Ten (10) questions were raised with regard to their relationships with their teacher. Higher-achieving students recognized their teachers' effectiveness in preparing lessons $(\mathrm{F}=5.555, \mathrm{p}<.01)$, teachers' good subject knowledge $(\mathrm{F}=3.366, \mathrm{p}<.05)$, and openness to give advice $(\mathrm{F}=4.791, \mathrm{p}<.05)$. It is apparent that when higher-achieving students have difficulties or private problems, they will seek out their teacher for counseling, particularly if the relationship is sufficiently close and if it is based on strong mutual trust.

\section{Student Respondents and Links with Community and Voluntary Services}

In general, students did not participate in voluntary service for their respective communities (70.3\%). However, higher-achieving students were more involved in voluntary services than lower-achieving students. They are more informed about youth programs and recognize the importance of decision-makers in the community who meet with the youth and discuss matters. Most of these students expressed intentions to participate in youth events in the community.

There were seven (7) questions directed to the students to establish their satisfaction with environmental conditions in the community. According to Coleman (1994), tight community relationships as a resource would be enhanced by good security such as the ability to walk freely on the streets in neighborhoods; this will engender more amicable 
exchanges between community members. The sense of ease with community and satisfaction with overall security seems to have impacted positively on higher-achieving students $(\mathrm{F}=7.343, \mathrm{p}<.01)$. Higher-achieving students are more satisfied with facilities: for example, library and playground in the community $(\mathrm{F}=3.115, \mathrm{p}<.05)$. The facilities of a community in terms of study services and space and desired activities for youth have a positive influence on educational achievement.

\section{A Closer Look at the Roles of Fathers, Mothers, and the School}

\section{Relationships Between a Father and his Child}

Three (3) of the 16 items showed significant results in regard to relationships between fathers and their children. Higher achievement is nurtured and encouraged by the father's expressions of concern and his expectations and support for his child's success in school. At this point, the significant results are as follows: fathers of higher-achieving students were those who know their children's register class number $(\mathrm{F}=4.875, \mathrm{p}<.01)$, have high expectations for their children's education, and encourage good achievement $(\mathrm{F}=3.266$, $\mathrm{p}<.05)$. Such fathers spare no expense for the child's education and school support $(\mathrm{F}=7.888$, $\mathrm{p}<.01)$. 
Table 6: Relationships Between Fathers and Children

\begin{tabular}{|c|c|c|c|c|c|}
\hline Relationship with Children & a $\mathbf{M}(\mathbf{S d})$ & b M(Sd) & c $\mathbf{M}(\mathbf{S d})$ & $\begin{array}{l}\text { Total } \\
\text { M(Sd) }\end{array}$ & $\mathbf{F}(\mathbf{P})$ \\
\hline $\begin{array}{l}\text { I know what my child's weak } \\
\text { subject is }\end{array}$ & $\begin{array}{c}3.79 \\
(.978)\end{array}$ & $\begin{array}{l}3.60 \\
(.968)\end{array}$ & $\begin{array}{c}3.91 \\
(.900)\end{array}$ & $\begin{array}{l}3.37 \\
(.89)\end{array}$ & $\begin{array}{l}1.095 \\
(.338)\end{array}$ \\
\hline $\begin{array}{l}\text { I know who my child's closest } \\
\text { friend is }\end{array}$ & $\begin{array}{c}3.65 \\
(1.070) \\
\end{array}$ & $\begin{array}{c}3.30 \\
(.837)\end{array}$ & $\begin{array}{c}3.33 \\
(.905)\end{array}$ & $\begin{array}{l}3.42 \\
(.94)\end{array}$ & $\begin{array}{l}1.421 \\
(.246)\end{array}$ \\
\hline $\begin{array}{l}\text { I know my child's register class } \\
\text { number }\end{array}$ & $\begin{array}{l}4.00 \mathrm{~b} \\
(1.255)\end{array}$ & $\begin{array}{l}3.03 \mathrm{c} \\
(1.299\end{array}$ & $\begin{array}{c}3.62 \mathrm{bc} \\
(1.1)\end{array}$ & $\begin{array}{l}3.58 \\
(1.2)\end{array}$ & $\begin{array}{c}4.875 * * \\
(.009)\end{array}$ \\
\hline $\begin{array}{l}\text { I have high expectations of my child } \\
\text { and expect good results }\end{array}$ & $\begin{array}{c}4.59 \\
(.557)\end{array}$ & $\begin{array}{c}4.63 \\
(.556)\end{array}$ & $\begin{array}{c}4.33 \\
(.564)\end{array}$ & $\begin{array}{l}4.50 \\
(.57)\end{array}$ & $\begin{array}{l}3.266^{*} \\
(.042)\end{array}$ \\
\hline $\begin{array}{l}\text { My child has a strong sense of } \\
\text { responsibility }\end{array}$ & $\begin{array}{c}4.24 \\
(.699)\end{array}$ & $\begin{array}{c}4.40 \\
(.724)\end{array}$ & $\begin{array}{c}3.98 \\
(.876)\end{array}$ & $\begin{array}{c}4.18 \\
(.795)\end{array}$ & $\begin{array}{l}2.746 \\
(.069)\end{array}$ \\
\hline I trust my child in whatever happens & $\begin{array}{c}4.38 \\
(.679)\end{array}$ & $\begin{array}{c}4.28 \\
(.649)\end{array}$ & $\begin{array}{c}4.24 \\
(.679)\end{array}$ & $\begin{array}{c}4.30 \\
(.673)\end{array}$ & $\begin{array}{l}.420 \\
(.658)\end{array}$ \\
\hline $\begin{array}{l}\text { When trouble has arisen between } \\
\text { my child and I, I try to understand } \\
\text { my child as a teenager }\end{array}$ & $\begin{array}{c}4.41 \\
(.657)\end{array}$ & $\begin{array}{c}4.28 \\
(.702)\end{array}$ & $\begin{array}{c}4.30 \\
(.553)\end{array}$ & $\begin{array}{l}4.33 \\
(.62)\end{array}$ & $\begin{array}{c}.459 \\
(.633)\end{array}$ \\
\hline $\begin{array}{l}\text { When my child makes a mistake, I } \\
\text { reprimand my child about the } \\
\text { mistake }\end{array}$ & $\begin{array}{l}3.50 \\
(.707)\end{array}$ & $\begin{array}{c}3.82 \\
(1.020)\end{array}$ & $\begin{array}{c}3.64 \\
(.908)\end{array}$ & $\begin{array}{l}3.65 \\
(.88)\end{array}$ & $\begin{array}{l}1.133 \\
(.326)\end{array}$ \\
\hline $\begin{array}{l}\text { I have often spoken to my child } \\
\text { about what she/he will do after } \\
\text { graduation }\end{array}$ & $\begin{array}{c}3.94 \\
(.851)\end{array}$ & $\begin{array}{c}4.10 \\
(.803)\end{array}$ & $\begin{array}{c}3.77 \\
(1.008)\end{array}$ & $\begin{array}{l}3.92 \\
(.90)\end{array}$ & $\begin{array}{l}1.180 \\
(.311)\end{array}$ \\
\hline $\begin{array}{l}\text { I have rules for my child and } \\
\text { explain why they are necessary }\end{array}$ & $\begin{array}{c}3.79 \\
(.808)\end{array}$ & $\begin{array}{c}3.80 \\
(.847)\end{array}$ & $\begin{array}{c}3.77 \\
(.711)\end{array}$ & $\begin{array}{l}3.79 \\
(.77)\end{array}$ & $\begin{array}{l}.013 \\
(.987)\end{array}$ \\
\hline $\begin{array}{l}\text { When my child makes choices about } \\
\text { something, I usually give some } \\
\text { advice }\end{array}$ & $\begin{array}{c}4.09 \\
(.712)\end{array}$ & $\begin{array}{c}3.97 \\
(.928)\end{array}$ & $\begin{array}{c}3.82 \\
(.716)\end{array}$ & $\begin{array}{l}3.94 \\
(.78)\end{array}$ & $\begin{array}{l}1.146 \\
(.322)\end{array}$ \\
\hline $\begin{array}{l}\text { I approve of my child's } \\
\text { acquaintances of the opposite sex }\end{array}$ & $\begin{array}{c}3.68 \\
(.768)\end{array}$ & $\begin{array}{c}3.17 \\
(1.262)\end{array}$ & $\begin{array}{l}3.56 \\
(.918)\end{array}$ & $\begin{array}{l}3.49 \\
(.99)\end{array}$ & $\begin{array}{l}2.327 \\
(.103)\end{array}$ \\
\hline $\begin{array}{l}\text { I hope my child makes a good } \\
\text { choice in terms of profession (e.g., } \\
\text { lawyer, medical doctor, politician) }\end{array}$ & $\begin{array}{c}4.24 \\
(.781)\end{array}$ & $\begin{array}{c}4.41 \\
(.907)\end{array}$ & $\begin{array}{c}4.02 \\
(.621)\end{array}$ & $\begin{array}{l}4.19 \\
(.76)\end{array}$ & $\begin{array}{l}2.433 \\
(.093)\end{array}$ \\
\hline $\begin{array}{l}\text { I spare no expense for education and } \\
\text { school support }\end{array}$ & $\begin{array}{l}4.38 \mathrm{~b} \\
(.779)\end{array}$ & $\begin{array}{l}4.75 b \\
(.774)\end{array}$ & $\begin{array}{l}3.87 \mathrm{c} \\
(.894)\end{array}$ & $\begin{array}{l}4.22 \\
(.87) \\
\end{array}$ & $\begin{array}{c}7.388^{* *} \\
(.001)\end{array}$ \\
\hline $\begin{array}{l}\text { When I do my planning, I consider } \\
\text { my child's school schedule (test } \\
\text { period, deadline of project) }\end{array}$ & $\begin{array}{c}3.26 \\
(1.109)\end{array}$ & $\begin{array}{c}3.10 \\
(1.322)\end{array}$ & $\begin{array}{c}2.91 \\
(1.125)\end{array}$ & $\begin{array}{l}3.07 \\
(1.7)\end{array}$ & $\begin{array}{c}.884 \\
(.416)\end{array}$ \\
\hline $\begin{array}{l}\text { I emphasise fraternal love to my } \\
\text { child (if you have more than two } \\
\text { children) }\end{array}$ & $\begin{array}{l}3.85 \\
(.857)\end{array}$ & $\begin{array}{c}3.77 \\
(1.006)\end{array}$ & $\begin{array}{l}3.89 \\
(.841)\end{array}$ & $\begin{array}{l}3.84 \\
(.88)\end{array}$ & $\begin{array}{l}.163 \\
(.850)\end{array}$ \\
\hline
\end{tabular}

${ }^{*} p<.05,{ }^{* *} p<.01$

\section{Relationships Between a Mother and her Child}

The higher the achievement of students, the more important the relationship with their mothers seems to be. There were six (6) significant associations noted. A significant 
association was found between high achievement and mothers who knew their children's register class number $(\mathrm{F}=3.991, \mathrm{p}<.05)$. Mothers of higher-achieving students trust their children "whatever happens" $(\mathrm{F}=3.423, \mathrm{p}<.05)$ and have a deep understanding of their child and his/her needs $(\mathrm{F}=3.619, \mathrm{p}<.05)$. They have also most often spoken to them about what they could do after graduation $(\mathrm{F}=5.140, \mathrm{p}<.01)$. These mothers also spare no expense for their children's education and school support $(F=4.042, \mathrm{p}<.06)$. In the case of the higherachieving students, their mothers' planning entailed sticking to their child's school schedule, for example, test periods and deadline of projects, etc. $(\mathrm{F}=4.740, \mathrm{P}<0.05)$. 
Table 7: Relationships between a Mother and Children

\begin{tabular}{|c|c|c|c|c|c|}
\hline Relationship with children & a M(Sd) & b M(Sd) & c $\mathbf{M}(\mathbf{S d})$ & $\begin{array}{l}\text { Total } \\
\text { M(Sd) }\end{array}$ & $\mathbf{F}(\mathbf{P})$ \\
\hline $\begin{array}{l}\text { I know what my child's weak } \\
\text { subject is }\end{array}$ & $\begin{array}{c}4.44 \\
(.504)\end{array}$ & $\begin{array}{c}4.59 \\
(.560)\end{array}$ & $\begin{array}{c}4.41 \\
(.698)\end{array}$ & $\begin{array}{c}4.47 \\
(.610)\end{array}$ & $\begin{array}{c}.928 \\
(.398)\end{array}$ \\
\hline $\begin{array}{l}\text { I know who my child's closest } \\
\text { friend is }\end{array}$ & $\begin{array}{c}4.26 \\
(.618)\end{array}$ & $\begin{array}{c}4.44 \\
(.801)\end{array}$ & $\begin{array}{c}4.25 \\
(.659)\end{array}$ & $\begin{array}{c}4.31 \\
(.688)\end{array}$ & $\begin{array}{l}.783 \\
(.460)\end{array}$ \\
\hline $\begin{array}{l}\text { I know my child's register class } \\
\text { number }\end{array}$ & $\begin{array}{l}4.88 b \\
(.327)\end{array}$ & $\begin{array}{l}4.50 \mathrm{c} \\
(.672)\end{array}$ & $\begin{array}{l}4.61 b c \\
(.635)\end{array}$ & $\begin{array}{c}4.66 \\
(.590)\end{array}$ & $\begin{array}{l}3.991^{*} \\
(.021)\end{array}$ \\
\hline $\begin{array}{l}\text { I have high expectations of my } \\
\text { child's education and expect good } \\
\text { results }\end{array}$ & $\begin{array}{c}4.53 \\
(.5 .68)\end{array}$ & $\begin{array}{c}4.47 \\
(.567)\end{array}$ & $\begin{array}{c}4.43 \\
(.608)\end{array}$ & $\begin{array}{c}4.47 \\
(.581)\end{array}$ & $\begin{array}{l}.287 \\
(.751)\end{array}$ \\
\hline $\begin{array}{l}\text { My child has a strong sense of } \\
\text { responsibility }\end{array}$ & $\begin{array}{c}4.50 \\
(.615)\end{array}$ & $\begin{array}{l}4.50 \\
(.672)\end{array}$ & $\begin{array}{l}4.20 \\
(.960)\end{array}$ & $\begin{array}{c}4.37 \\
(.805)\end{array}$ & $\begin{array}{l}2.088 \\
(.129)\end{array}$ \\
\hline I trust my child in whatever happens & $\begin{array}{c}4.65 \\
(.544)\end{array}$ & $\begin{array}{c}4.61 \\
(.615)\end{array}$ & $\begin{array}{c}4.28 \\
(.858)\end{array}$ & $\begin{array}{c}4.48 \\
(.730)\end{array}$ & $\begin{array}{l}3.423^{*} \\
(.036)\end{array}$ \\
\hline $\begin{array}{l}\text { When trouble has arisen between } \\
\text { my child and I, I try to understand } \\
\text { my child as a teenager }\end{array}$ & $\begin{array}{c}4.53 \\
(.563)\end{array}$ & $\begin{array}{c}4.53 \\
(.671)\end{array}$ & $\begin{array}{c}4.16 \\
(.880)\end{array}$ & $\begin{array}{c}4.37 \\
(.761)\end{array}$ & $\begin{array}{l}3.619^{*} \\
(.030)\end{array}$ \\
\hline $\begin{array}{l}\text { When my child makes a mistake, I } \\
\text { reprimand my child about the } \\
\text { mistake }\end{array}$ & $\begin{array}{c}4.00 \\
(.612)\end{array}$ & $\begin{array}{c}3.91 \\
(.777)\end{array}$ & $\begin{array}{c}3.88 \\
(.909)\end{array}$ & $\begin{array}{c}3.92 \\
(.793)\end{array}$ & $\begin{array}{c}.227 \\
(.798)\end{array}$ \\
\hline $\begin{array}{l}\text { I have often spoken to my child } \\
\text { about what she/he will do after } \\
\text { graduation }\end{array}$ & $\begin{array}{l}4.29 b c \\
(.524)\end{array}$ & $\begin{array}{l}4.41 b \\
(.615)\end{array}$ & $\begin{array}{l}3.96 \mathrm{c} \\
(.763)\end{array}$ & $\begin{array}{c}4.18 \\
(.683)\end{array}$ & $\begin{array}{c}5.140 * * \\
(.007)\end{array}$ \\
\hline $\begin{array}{l}\text { I have rules for my child and } \\
\text { explain why they are necessary }\end{array}$ & $\begin{array}{c}4.06 \\
(.736) \\
\end{array}$ & $\begin{array}{l}4.09( \\
.734) \\
\end{array}$ & $\begin{array}{c}3.88 \\
(.824)\end{array}$ & $\begin{array}{c}3.99 \\
(.775)\end{array}$ & $\begin{array}{l}.924 \\
(.400)\end{array}$ \\
\hline $\begin{array}{l}\text { When my child makes choices about } \\
\text { something, I usually give some } \\
\text { advice }\end{array}$ & $\begin{array}{c}4.27(.51 \\
7)\end{array}$ & $\begin{array}{c}4.38(.60 \\
9)\end{array}$ & $\begin{array}{c}4.14 \\
(.664)\end{array}$ & $\begin{array}{c}4.24 \\
(.613)\end{array}$ & $\begin{array}{l}1.553 \\
(.216)\end{array}$ \\
\hline $\begin{array}{l}\text { I approve of my child's } \\
\text { acquaintances of the opposite sex }\end{array}$ & $\begin{array}{c}2.74(.86 \\
4)\end{array}$ & $\begin{array}{l}2.91(1.0 \\
27)\end{array}$ & $\begin{array}{c}3.14(1.1 \\
32)\end{array}$ & $\begin{array}{l}2.96(1.0 \\
37)\end{array}$ & $\begin{array}{l}1.602 \\
(.206)\end{array}$ \\
\hline $\begin{array}{l}\text { I hope my child makes a good } \\
\text { choice in terms of profession (e.g., } \\
\text { lawyer, medical doctor, politician) }\end{array}$ & $\begin{array}{c}4.42(.56 \\
4)\end{array}$ & $\begin{array}{c}4.22(1.0 \\
08)\end{array}$ & $\begin{array}{c}4.04(.99 \\
9)\end{array}$ & $\begin{array}{c}4.20(.90 \\
9)\end{array}$ & $\begin{array}{l}1.681 \\
(.191)\end{array}$ \\
\hline $\begin{array}{l}\text { I spare no expense for education and } \\
\text { school support }\end{array}$ & $\begin{array}{c}4.53 \\
(.563)\end{array}$ & $\begin{array}{c}4.48 \\
(.851)\end{array}$ & $\begin{array}{c}4.04 \\
(1.058)\end{array}$ & $\begin{array}{c}4.30 \\
(.906)\end{array}$ & $\begin{array}{l}4.042^{*} \\
(.020)\end{array}$ \\
\hline $\begin{array}{l}\text { When I do my planning, I consider } \\
\text { my child's school schedule (e.g., } \\
\text { test period, deadline of project) }\end{array}$ & $\begin{array}{l}4.09 b c \\
(.900)\end{array}$ & $\begin{array}{l}4.47 b \\
(.761)\end{array}$ & $\begin{array}{l}3.80 \mathrm{c} \\
(1.096)\end{array}$ & $\begin{array}{c}4.07 \\
(.989)\end{array}$ & $\begin{array}{l}4.740^{*} \\
(.011)\end{array}$ \\
\hline $\begin{array}{l}\text { I emphasise fraternal love to my } \\
\text { child (if you have more than two } \\
\text { children) }\end{array}$ & $\begin{array}{l}4.03 \\
(.684)\end{array}$ & $\begin{array}{c}4.22 \\
(.870)\end{array}$ & $\begin{array}{l}3.96 \\
(.747)\end{array}$ & $\begin{array}{l}4.05 \\
(.767)\end{array}$ & $\begin{array}{l}1.132 \\
(.326)\end{array}$ \\
\hline
\end{tabular}

When reviewing the data, an interesting finding emerged: If a father has not visited his child's school during the past twelve months, this does not affect the child's results too negatively. However, if the father makes an effort to go to his child's school at least once in 
the year, this will most likely result in higher achievement $\left(\chi^{2}=12.486, p<.05\right)$. On the contrary, if mothers have gone to their children's school only once over the year, the achievement of their children will be low. The tendency, however, is for South Korean mothers to visit the school repeatedly. In the cases where this happens, children will achieve even better results $\left(\chi^{2}=11.067, \mathrm{p}<.05\right)$. Mothers of high-achieving students are often more socially connected and more involved in cooperative educational group activities with other parents (in their child's interest) than mothers of lower-achieving students $(F=10.602, p<.05)$.

Mothers generally collect more educational information for their children than do fathers. It is clear that higher-achieving students are somewhat dependent on educational information gained by their mothers. Collected educational information entails, for example, details on essay-writing, or reports on the well-known Hakwgwan (a private educational institution in South Korea) offering special tutoring for the child. Mothers seek out such useful information to drive higher achievement.

To illustrate qualitatively the differences between the attitudes of fathers and mothers, we interviewed three family members; the son who was interviewed lived in a dormitory since he was a boarding student. Parts of the interviews are referred to below. All members were interviewed separately. Only selected questions are offered below:

Question: Describe to me how involved you are in your child's studies? Tell me about it.

Father's response: I am always interested in my child's studies but I don't seem to be able to talk about those things ... because my son does not want to know about his studies. It means that he feels the pressure of studies on his own, in my opinion. [translated from Korean]

Mother's response: I am involved in almost every aspect of his studies. For example, I am interested in his school life, how he performs in his grade ... and even if he is dating! To mention something in particular, I am strongly involved in his study; ... I make a schedule for his study and preparation for the exams, I guide him on how he may be assessed and also about the kind of competition he faces. In case of a competition, I sometimes give some advice to him on when we should plan for a competition and then I give him ideas for the topic. [translated from Korean]

From these answers, one sees resilience on the mother's side but a more casual attitude from the father. The quantitative results reveal that where fathers make a visible 
effort to show an interest in their child's studies the child's performance is boosted. Here, the father does not seem to know how to connect with his son but is pleased that his son "feels the pressure" and is thus self-driven.

Question: How do you motivate your son?

Father's response: I just preach to him to study. [translated from Korean]

Mother's response: I think he has low self-confidence with regard to his studies. That is why I have to encourage him constantly ... telling him that he can do well ... using good words. [translated from Korean]

Son's response: (to the question of how he experiences his parents' efforts): She is strongly involved in my studies and everything... In particular, because she is a [...] teacher she helps me to prepare for performance assessments and competitions.... She helps a lot with study competitions ... but both my parents motivate me through a lot of preaching.... Nowadays it is about self-study. Since [I'm in] in the higher grade, I have to ask: "What do I do for my future?" This then encourages me to study by myself. [translated from Korean]

Follow-up question: But if your parents did not encourage you in the way that you described earlier, would you do as well in school?

Son's response: I am maintaining my own standard. [translated from Korean].

The interviews show that the son in question has a strong awareness of the roles of his parents, but he suggested that he was "maintaining his own standard" by being selfmotivated. The strong role of his mother and infrastructure of social support and "preaching" from both parents keep him alert and attentive to what needs to be done for his future. Parental support thus offered the foundation, but the intermittent distance which comes with being a boarding school student appears to have strengthened his independence and initiative.

\section{Relationships Between Mothers, Fathers and Teachers}

The quantitative results suggest that mothers strike up and sustain good relationships with their children's school teacher(s). However, they do not necessarily have the best relationship with their children's teachers, when compared with fathers. Fathers of higherachieving students tend to view their children and their teacher as respectful towards each other $(\mathrm{F}=4.956, \mathrm{p}<.01)$. They agree that their children and their teachers have good 
interactions with each other at school $(\mathrm{F}=5.343, \mathrm{p}<.01)$. They acknowledge teachers who have a passion for high quality education $(\mathrm{F}=4.717, \mathrm{p}<.05)$ and display pride in their child's school $(\mathrm{F}=9.123, \mathrm{p}<.01)$. Their sense of satisfaction with the child's teacher has positive spinoffs for their child's education. Mothers were found to demand more of the teachers than fathers, and consequently they expressed less satisfaction in their children's teacher.

Nonetheless, mothers of high-achieving students were proud of their child's school ( $\mathrm{F}=6.922$, $\mathrm{p}<.01$ ). It seems evident that the pride internalized with regard to their children's school helps boost children's attitudes and receptiveness and enhances their educational achievement positively.

Finally, in reviewing the study's general results, one can draw on Coleman's (1998) faith in social capital as embodied in social relations: familial social capital connects with social capital emanating from beyond the family, within and outside the school, and in the surrounding community. A number of recommendations can be considered by families, teachers, and policy-makers seeking to improve the performances of students who are underachieving or performing poorly. A select five recommendations are offered below, focused on familial social capital and borne out of the data analysis.

\section{Recommendations}

\section{Recommendation 1: Prioritise the encouraging of stronger affective bonds between fathers and their children}

Father's roles tend to be defined by their economic contributions in the family, thus, decision-making at the domestic and expressive levels, whether it is about choice of schools or child-rearing in general is often seen as the domain of wives or mothers (Cabrera et al., 2000). Fathers should be actively encouraged through the media and school newsletters and other networks to engage in new family-friendly routines. Sustaining closer contact (Carlson, 2006; Soblewski \& King, 2005) and spending more time with children engenders more selfassured and focused children. Thus, the importance of a close relationship between father and children cannot be over-emphasised. In the interests of high achievement but also in the interests of building an equitable society, one that acknowledges that fatherhood should be equally important as motherhood in the life of the child.

\section{Recommendation 2: Encourage students to take responsibility for their own learning outcomes}

This study has shown that boarding school students have a significantly higher achievement than students who stay at home. Leaving home at an early age seems to result in 
better academic results than does leaving home at a later stage. It may be that separation from parents at the high school level creates a creative and independent space facilitating better results and an opportunity to excel. A self-study process can be effectively used as a base for effective planning and is likely to have a great effect on achievement (Kells, 1980; Kim 2011). Although emphasis has been placed on building good relationships between fathers and their children, studying is really an activity paced and pursued by individual students. Parents, educators, and policymakers should undertake to place more emphasis on improving student capabilities for self-directedness and self-study.

\section{Recommendation 3: Participate in networks to collect vital resources to enhance children's successful performance}

This study reveals that the structural dimension of social capital is important. The research shows that most high-achieving students' mothers are involved in their children's school life (Coleman, 1988; Fursenberg \& Hughes, 1995; Lee, 2001; Putnam, 1994). These mothers also shared and exchanged educational information potentially leading to high achievement through their networks (Coleman, 1994). They collected educational information, for example, to find out about well-known private educational institutions and effective tutoring for higher achievement. A large proportion of high-achieving students' mothers were full-time housewives, and they involve themselves in select offline groups. These groups, however, exclude working mothers. Therefore, policymakers and educators need to consider the situation of working mothers and actively promote online networks that incorporate their interests.

\section{Recommendation 4: Nurture amicable relationships between teachers and students}

South Korean students seem to think that "a good teacher" and "good teaching" are not quite the same thing. A strict temperament might be seen to be characteristic of thorough and orderly or good teaching, but the person performing as such in the classroom is rarely considered by students to be the "good teacher" (Murphy et al., 2004). Schools should promote the idea of a good teacher as a good person: one who communicates effectively, meticulously, and with enthusiasm. A good teacher is furthermore one who understands his/her role in a holistic sense (Hamachek, 1969). As a group of social actors with a collective societal responsibility, good teachers need to demonstrate trust. Top-performing students had strong trust in their teachers. Teachers, thus, need to re-think their roles by integrating an affective, counseling, compassionate component. The new global environment requires teachers who are versatile and dynamic and not simply instrumental. 


\section{Recommendation 5: Improve Community Security}

Community security and educational achievement are positively correlated (Coleman, 1988; Putnam, 2001; Sun, 1998). Good security is a resource in the community, particularly when people of all ages are able to walk on the street without fear or anxiety (Coleman, 1994; Putnam, 1994). Previous research shows that social trust or political cooperation and participation in the community is positively related to good educational outcomes (Braatz \& Putnam, 1996). The current study reiterates that by strengthening a sense of security and assurance, higher achievement amongst a wider spectrum of students is likely to become evident. Admittedly, good community security coincides with the status of neigbourhoods and their economic resources. Peaceful spaces in which to learn and engage in intellectual work is vital for long-term and sustained achievement.

\section{Conclusion}

Original data is offered in this article that finds synergy with Coleman's assertions on the primacy of family and the significance of parental involvement. What is new is the clear distinction between the effects of the maternal and paternal roles and the suggestion that greater participation from men (fathers or guardians) are likely to have positive benefits on academic achievement. A network of care and concern offers a foundation of assurance useful for academic outcomes. However, while close bonds are crucial for children's success, it was interesting to find that some degree of separation also works to their advantage, as evidenced by the strong performances of boarding school students. Knowing that family support is accessible, if and when needed, helps facilitate their independence and sense of ownership over their own learning outcomes.

Teachers should, in noting the importance of families, seek to build positive relationships with parents and also emulate positive expressions of care in their relationships with students in the course of enhancing their skills to become autonomous learners. While school social capital should not be undervalued, it should also not be simplistically assumed that private schools are always advantageous and public schools incapable of generating exceptionally strong results. The public school in this study did remarkably well. In this regard, the agency of teachers should be acknowledged. Strong trust between a teacher and a student positively contributes to students' educational achievement. Giving affective support to students engenders deep trust more so than having expert subject knowledge. From a cognitive perspective, when students are satisfied and comfortable with the school - ts policies and ethos - this leads to higher achievement. When a school and its students are in 
harmony about the rules and rhythm there is mutual satisfaction, shared values, and common understandings.

With respect to community social capital, the results were found to be insignificant. Nevertheless, the structural dimension of residential district is important in influencing higher achievement outcomes. It is true that Gangnam is a wealthy neighbourhood and exists as an economic hub of South Korea. It is in some ways unique when compared to other districts, with Gangnam mothers exhibiting extraordinary resilience in keeping abreast of children's schedules and activities and taking deliberate steps to ensure that their children reap advantages. All things considered, close relationships between both parents (or guardians) and their children cannot be over-emphasised. Nurturing this would be in the interest of promoting not just high achievement but that of building an equitable society: one that acknowledges that fatherhood should be equally important as motherhood in the life of the child. 


\section{References}

Adler, P. S. \& Kwon, S. W. (2002). Social capital: Prospects for a new concept. The Academy of Management Review, 27(1): 17-40.

An, W. H. (2005). 가족 내 사회적 자본과 학업성취와의 관계 [The analysis of the relationship between family social capital and academic achievement]. Korea: Korea study information.

Bae, N. P (2007). 미국명문대 진학률 비결은 [The key for the Ivy league is] Retrieved from http://article.joins.com/article/article.asp?Total_ID=2966834

Braatz, J. \& Putnam, R. D. (1996). Community-based social capital and educational performance: exploring new evidence. Cambridge: Harvard University.

Bourdieu, P. (1998) Translated by Clough, Lauretta C. The state nobility: Elite schools in the field of power. Pierre Bourdieu with the collaboration of Monique de Saint Martin. Cambridge: Polity Press.

Buchmann, C. \& Hannum, E. (2001). Education and stratification in developing countries: A review of theories and research. Annual Review of Sociology, 27: 77-102.

Cabrera, N. J., Tamis-LeMonda, C. S., Bradley, R. H., Hofferth, S., \& Lamb, M. E. (2000). Fatherhood in the twenty-first century. Child Development, 71(1): 127-136.

Carlson, M. J. (2006). Family structure, father involvement, and adolescent behavioral outcomes. Journal of Marriage and Family, 68(1): 137-154. Retrieved from http://www.jstor.org

Chang, K. (2010) South Korea under compressed modernity: Familial political economy in transition. New York: Routledge.

Choi, H. (2009, 6 December). Obama, "Korean children no computer games and no TV". The Hankook Times online. Retrieved from http://news.hankooki.com/lpage/world/200912/h2009120622163222470.htm

Clark, Donald N. (2000). Culture and customs of Korea. London: Greenwood Press.

Coleman, J. (1988). Social capital in the creation of human capital. The American Journal of Sociology, 94: S95-S120.

Coleman, J. (1994) Foundations of social theory. Cambridge, MA: The Belknap Press of Harvard University Press.

Coleman, J. \& Hoffer, T. (1987). Public and private high schools: The impact of communities. New York: Basic Books. 
Dika, S. L. \& Singh, K. (2002). Applications of social capital in educational literature: A critical synthesis. Review of Educational Research, 72(1): 31-60.

Field, J. (2008) Social capital. Second Edition. New York: Routledge.

Furstenberg, F. F. \& Hughes, M. E. (1995). Social capital and successful development among at-risk youth. Journal of Marriage and the Family, 57(3): 580-592.

Halpern, D. (2005) Social capital. Cambridge: Polity.

Hamachek, D. (1969). Characteristics of good teachers and implications for teacher Eeucation. Phi Delta Kappan, 50: 341-344

Hanifan, L. J. (1916). The rural school community center. Annals of the American Academy of Political and Social Science, 67:130-138. Retrieved from http://www.jstor.org/stable/1013498

Israel, G. D., Beaulieu, L. J., \& Hartless, G. (2001). The influence of family and community social capital on educational achievement. Rural Sociology, 66(1): 43-68.

Jang, S. S. (1999). 한국 사회의 교육수준별 혼인 유형과 그 변화 [Marriage type and the change by educational level in Korean society]. Seoul: 한국 사회학 [Korea Sociology], 33: 417-448.

Jeong, I. \& Armer, M. (1994). State, class, and expansion of education in South Korea: A general model. Comparative Education Review, 38(4):531-545.

Jin, Y. N. (2006). 교육 환경이 주택 가격에 미치는 효과에 관한 실증적 분석: 서울 특별시를 중심으로 [An empirical study of the effects of educational variable on housing prices: Case of Seoul apartment market]. Seoul: Doctoral dissertation, The Konkuk University.

Kells, H. R. (1980). The purposes and legacy of effective self-study processes: enhancing the study planning cycle. The Journal of Higher Education, 51(4): 439-447. Retrieved from http://www.jstor.org/stable/1981052

Kim, H. (2011). 왜자기주도학습이 사교육보다 중요한가?. [Why is self-directed learning is more important than private tutoring?]. Korea Development Institute (KDI) Policy Forum, 231(1): 1-18.

Kim, J. Y. (2005) ."Bowling together” isn't a cure-all: The relationship between social capital and political trust in South Korea. International Political Science Review, 26(2): 193-213. 
Kim, K. O., Kim, D. I., Suh, Y. J., \& Rhee, C. Y. (2004). 입시제도의변화: 누가 서울대학교에 들어오는가? [Change of entrance examination: Who enters Seoul National University?)]. 한국사회과학 [Korean Social Science], 25(1\&2):3-187.

Kim, S. \& Lee, J. (2006). Changing facets of Korean higher education: Market competition and the role of the state. Higher Education, 52(3): 557-587. Retrieved from http://www.jstor.org/stable/29735026

Kim, Y. H. (1999). Recent developments in Korean school education. KEDI: School Effectiveness and School Improvement, 10(1): 55-71.

Lee, J. S. (2001). 학업성취도와 사회적 자본의 관계: 기술적 문화연구 [Relationships between academic achievement and social capital: Research of technical culture]. 교육민속학연구 [Research of Educational Anthropology], 4(3): 253-288.

Morris, P. (1996). Asia's four little tigers: A comparison of the role of education in their development. Comparative Education, 32(1): 95-109.

Muijs, D. (2011). Doing quantitative research in education with SPSS (2nd ed.). London: Sage.

Murphy, P. K., Delli, L. A. M., \& Edwards, M. N. (2004). The good teacher and good teaching: Comparing beliefs of second-grade students, preservice teachers, and in-service teachers. The Journal of Experimental Education, 72(2): 69-92. Retrieved from www.jstor.org/stable/20157360

Nahapiet, J., \& Ghoshal, S. (1998). Social capital, intellectual capital, and theorganizational advantage. The Academic Management Review, 23(2): 242-266.

Oh, O. W. (2000). 한국 사회 교육열: 기원과 심화 [Educational zeal in Korean society: the source and deepening]. Seoul: 교육 과학사 [Kyoyukwahaksa].

Perna, L. W. \& Titus, M. A. (2005). The relationship between parental involvement as social capital and college enrollment: An examination of racial/ethnic groupdifferences. The Journal of Higher Education, 76(5): 485-518.

Putnam, R. D. (1994). Social capital and public affairs. Bulletin of the American Academy of Arts and Sciences, 47(8): 5-19.

Putnam, R. D. (1995). Tuning in, tuning out: The strange disappearance of social capital in America. Political Science and Politics, 28(4): 664-683.

Putnam, R. D. (2001). Bowling alone: The collapse and revival of American community. New York: Simon \& Schuster. 
Schneider, B. \& Lee, Y. (1990). A model for academic success: the school and home environment of East Asian students. Anthropology \& Education Quarterly, 21(4): 358377.

Shin, J. (2012). Higher education development in Korea: Western university ideas, Confucian tradition, and economic development. Higher education, 64(1): 59-72. Retrieved from http://www.jstor.org/stable/41477919

Sobolewski, J. M. \& King, V. (2005). The importance of the coparental relationship for nonresident fathers' ties to children. Journal of Marriage and Family, 67(5): 1196-1213.

Sorensen, C. W. (1994). Success and education in South Korea. Comparative Education Review, 38(1):10-35.

Sun, Y. (1998). The academic success of East-Asian American students: An investment model. Social Science Research, 27(4): 432-456.

Teachman, J. D., Paasch, K., \& Carver, K. (1996) .Social capital and dropping out of school early. Journal of Marriage and the Family, 58(3): 773-783.

Tsai, W. (2000). Social capital, strategic relatedness and the formation of intraorganizational linkages. Strategic Management Journal, 21(9): 925-939.

$\mathrm{Yu}, \mathrm{H}$. K. (2006). 사회계층과 교육격 차 [Social class and difference in education]. Seoul: 한국직업능력개발원 [Korea Research Institute for Vocational Education \& Training: KRIVET].

Whang, K. (2009) .미 아이비리그 진학 연 100명 시대로 [Admission of the Ivy League is to the age of 100 Korean students]. Retrieved from http://www.donga.com/fbin/output?n=200910020088

Wright, J. P., Gullen, F. T., \& Miller, J. T. (2001). Family social capital and delinquent involvement. Journal of Criminal Justice, 29: 1-9.

íSKY refers to the top three prestigious universities in Korea: S is Seoul National University, K is Korea University, and $\mathrm{Y}$ is Yonsei University. 